d'un indice combinant la vitesse de croissance, l'indice de consommation et l'épaisseur de lard mesurée à la réglette à 80 kilogrammee. Le choix des mères des verrats se faisait pratiquement au hasard dans les élevages de la zone soumise à l'insémination. La population femelle concernée comptait environ 5000 truies de type Large White réparties dans de nomhreux élevages de faibles dimensions. Parallèlement à cette sélection des mâles castrés et des femelles étaient mis à l'engraissement à 30 kilogrammes et al)attus à un poids vif voisin de 100 kilogrammes. Chaque année cet engraissement permettait de comparer la descendance des verrats sélectionnés l'année précédente à celle des verrats restants parmi les verrats sélectionnés deux ans plus tôt. Le progrès génétique ainsi estimé a été, en trois ans, de 30 grammes par jour en gain moyen entre 30 et 100 kilogrammes, de $-0,10$ en indice de consommation entre 30 et 80 kilogrammes et de $1,1 \mathrm{~mm}$ en épaisseur de lard sur la carcasse. Les estimations théoriques du progrès génétique, calculées à partir des peremètres génétiques du livre généalogique Large White (Ollivier, 1969, Journées de la Recherche Porcine, I.N.R.A. - I.T.P., Paris, 7-12) sont respectivement de 7 grammes, $-0,05$ et $-1,9 \mathrm{~mm}$ pour le gain moyen quotidien, l'indice de consommation et l'épaisseur de lard. La découpe des carcasses a montré que la diminution de l'épaisseur de lard s'est accompagnée d'une réduction notable du poids des morceaux gras (bardière et panne) mais qu'elle n'a pas entraîné un accroissement équivalent du poids des morceaux nobles (jambon et longe), ce qui s'est traduit par une diminution du rendement en carcasse. L'expérience se poursuit.

\title{
SOME POINTS OF VIEW ON THE ESTIMATION AND IMPORTANCE OF GENETIC CHANGE IN POPUI,ATIONS OF DAIRY CATTLE.
}

\author{
Ut, Lindstrïm. - Dep. Animal Breeding, Agric. Res. \\ Centre, Tikkurila, Finland.
}

Some results from a study on genetic changes in milk yield and fat percentage in the Finnish Ayrshire (ay) and Finncattle ( $f c$ ) hreeds are discussed. Moreover the economic importance of the genetic change is considered.

The genetic cbange was estimated in 2 ways : $(a)$ from the selection practised in artificial insemination (A I) in 1961-66 and (b) from the change in the progeny tests of individual AI sires over the period 1957-68.

The following results were ohtained and conclusions drawn :

1. The genetic gain in milk yield was in ay $0.80-0.91 \%$ /year and in $f c 0.84-0.99 \%$ /year. In kilograms this corresponds to some 35 and $31.5 \mathrm{~kg}$, respectively.

2. With regard to fat percentage no noticeahle genetic change could be detected in either breed.

3. As both methods used gave similar results it was concluded that the estimates can be regarded as fairly reliable.

4. In both breeds about one half of the increase in average milk yield noted over the period 1957-68 could be attributed to the breeding work.

5. The rate of interest on investments made in breeding was calculated to be $107 \%$. (The genetic gain achieved in one year was considered permanent, $i$. e. available also the following years. As costs those pertinent for AI, milk recording and Breed Societies were taken into account. On the return side the average genetic gain in milk yield on the two breeds $(0.93 \% / \mathrm{yr})$ was considered and multiplied by the appropriate economic production value).

6. The genetic gain in milk yield could from the level observed in the present study he increased to $1.4-1.5 \%$ /year. This would require :

a) that the best $1-2 \%$ of the bulls were approved as bull sires (in study $35 \%$ in ay and $25 \%$ in $f c$ )

b) that as sires of female replacement only $10-15 \%$ of the bults be approved (52\% in ay, $45 \%$ in $f c$ );

c) that average generation interval be decreased from the observed 7.3 years to 5.3 years. 